\title{
Features of lineage-specific hematopoietic metabolism revealed by mitochondrial proteomics
}

DOI:

10.1002/pmic.201700053

\section{Document Version}

Accepted author manuscript

Link to publication record in Manchester Research Explorer

\section{Citation for published version (APA):}

Billing, C., Walker, M., Noack, N., Böhme, C., Ceglarek, U., Niederwieser, D., Whetton, A., \& Cross, M. (2017). Features of lineage-specific hematopoietic metabolism revealed by mitochondrial proteomics. Proteomics, 17(1516). https://doi.org/10.1002/pmic.201700053

\section{Published in:}

Proteomics

\section{Citing this paper}

Please note that where the full-text provided on Manchester Research Explorer is the Author Accepted Manuscript or Proof version this may differ from the final Published version. If citing, it is advised that you check and use the publisher's definitive version.

\section{General rights}

Copyright and moral rights for the publications made accessible in the Research Explorer are retained by the authors and/or other copyright owners and it is a condition of accessing publications that users recognise and abide by the legal requirements associated with these rights.

\section{Takedown policy}

If you believe that this document breaches copyright please refer to the University of Manchester's Takedown Procedures [http://man.ac.uk/04Y6Bo] or contact uml.scholarlycommunications@manchester.ac.uk providing relevant details, so we can investigate your claim.

\section{OPEN ACCESS}




\section{Features of lineage-specific haematopoietic metabolism revealed by mitochondrial proteomics}

Claudia Billing ${ }^{1}$, Michael Walker ${ }^{2}$, Nicole Noack ${ }^{1}$, Christian Böhme $^{1}$, Uta Ceglarek $^{3}$, Dietger Niederwieser $^{1}$, Anthony Whetton ${ }^{2,4}$, Michael Cross ${ }^{1}$

${ }^{1}$ Department of Haematology and Oncology, University of Leipzig, Germany

${ }^{2}$ Stem Cell and Leukaemia Proteomics Laboratory, University of Manchester, Manchester Academic Health Science Centre, UK

${ }^{3}$ Institute of Laboratory Medicine Clinical Chemistry and Molecular Diagnostics, University of Leipzig, Germany

${ }^{4}$ Stoller Biomarker Discovery Centre, University of Manchester, UK

Corresponding author: Michael Cross PhD,

University of Leipzig Department of Hematology and Oncology, Johannisallee $32 \mathrm{~A}$,

04103 Leipzig,

Germany.

Tel. $+49(0) 3419713031$

Fax $+49(0) 3419713059$

Email: crossm@medizin.uni-leipzig.de

Abbreviations used in this paper: FDCP-Mix: Factor Dependent Cells Paterson - Mixed potential; SR: self-renewing; E: erythroid; M: myeloid.

Keywords: haematopoietic system; differentiation; mitochondria; metabolism; mouse 


\section{Abstract}

Hematopoietic bone marrow is a regenerative tissue of high clinical relevance, yet relatively little is known about the metabolism of the stem and progenitor populations concerned. We have used a multipotent murine cell line to generate sufficient numbers of cells undergoing self-renewal, erythroid or myeloid differentiation to allow a proteomics analysis of enriched mitochondria. Stringent analysis identified 37 mitochondria-associated proteins changing on differentiation in this system. Those induced during differentiation were commonly associated with mature cell functions, while those inactivated upon differentiation indicate widespread changes in mitochondrial transport, fatty acid catabolism and oxidative phosphorylation. An erythroid specific reduction in glutamate pyruvate amino transferase 2 was confirmed at the protein level by western blotting and at the functional level by assays of metabolite turnover. In addition to validating the dataset, these findings suggest significant differences in the coremetabolism between erythropoiesis and myelopoiesis. This knowledge is of relevance to the in vitro production of cell therapy products and to studies of the interdependence of metabolic and signaling pathways in regenerative tissues.

Data are available via ProteomeXchange with identifier PXD002968. 


\section{Significance of the study}

Bone marrow constantly produces vast numbers of both red and white cells in a closely packed environment that is likely to generate metabolic gradients and be subject to metabolic constraints. The proteome analysis presented here used mitochondria enriched from haematopoietic progenitors to identify stage- and lineage-specific changes indicative of metabolic shifts during blood cell differentiation. These findings have implications for our understanding of the bone marrow metabolic environment and the conditions that will be required to reproduce efficient blood cell production in vitro. Our data also provide a basis for targeted studies of the relationship between metabolic and signaling pathways during differentiation and for the identification of metabolic differences between normal and leukaemic blood cells. 


\section{Introduction}

Blood cell production in the bone marrow is regulated by a range of well characterised signaling molecules, but also by a metabolic environment about which we know relatively little. Recent studies suggest that the long-lived multipotent hematopoietic stem cells are maintained in a hypoxic niche, run a predominantly glycolytic metabolism and limit the accumulation of potentially damaging reactive oxygen species [1]. As these stem cells exit quiescence, a switch to fatty acid oxidation may provide the energy required for the initial divisions that generate both replacement stem cells and the multipotent progenitors that enter proliferative haematopoiesis [2]. However, the subsequent metabolism of proliferative differentiation along the various blood cell lineages is poorly characterized.

The two major products of hematopoiesis are erythroid cells and neutrophilic granulocytes. The early cell divisions in each lineage generate structurally similar blast cells with a high nucleus to cytoplasmic ratio, while later divisions are accompanied by progressive, lineagespecific changes. Neutrophils are high-energy cells poised to play an active role in host defense. The final stages of their maturation involve extensive biosynthesis and biogenesis to generate secretory granules and mitochondria poised to execute an oxidative burst [3]. In contrast, the final stages of erythropoiesis involve rounds of reductive division followed by extrusion of the nuclei and loss of the mitochondria. The emerging erythrocytes retain an exclusively cytoplasmic metabolism that serves primarily to provide protection against oxidative stress [4]. While the biosynthetic demands of progenitor proliferation are therefore similar for both lineages, the later stages of maturation are likely to have different metabolic requirements.

With the aim of comparing metabolic activities characteristic of proliferative differentiation along these two major lineages, we have studied erythroid and granulocytic differentiation of the multipotent murine precursor cell line, FDCP-Mix. The FDCP-Mix cells proliferate in the presence of high concentrations of interleukin-3 (IL-3) as a population of multipotent progenitors retaining the potential to generate both erythroid and myeloid cells. Transfer of these multipotent cells to media containing low concentrations of IL-3 together with either 
myeloid or erythroid growth factors supports proliferative differentiation along the corresponding lineage, culminating after a few days in post-mitotic maturation $[5,6]$. A proportion of the erythroid cells undergo enucleation and the mature neutrophils survive for a short time only, as is the case in vivo. The FDCP-Mix cells therefore provide a suitable model for studies requiring large numbers of hematopoietic cells at defined stages of differentiation. We report here a proteomics analysis of mitochondria purified from FDCP-Mix at various stages of differentiation that reveals stage and lineage-specific features, including an unexpected shift in glutamine metabolism during erythroid differentiation.

\section{Materials and Methods}

\section{Cell culture}

Multipotent FDCP-Mix cells were maintained in IMDM containing $5 \mathrm{mM}$ glucose, $2 \mathrm{mM}$ glutamine, $20 \%$ pre-tested horse serum and $10 \mathrm{U} / \mathrm{ml} \mathrm{mlL}-3$ (Peprotech). Cells were passaged every two days to maintain the density between $6 \times 10^{4}$ and $5 \times 10^{5}$ per ml. All culture procedures were carried out in an uninterrupted low oxygen atmosphere $\left(5 \% \mathrm{O}_{2}, 5 \%\right.$ $\mathrm{CO}_{2}$ in $\mathrm{N}_{2}$ ). Otherwise, differentiation was induced essentially as previously reported [5]. Glucose was replenished on the third day of myeloid differentiation. For experiments involving the determination of metabolite levels in culture supernatants, the serum was dialyzed extensively against PBS (10 kilodalton cut-off) to remove small metabolites. Human umbilical cord blood blood was collected following local ethical committee approval and informed consent of the parents. Mononuclear cells were purified over Lymphoprep (Stem Cell Technologies) and CD34+ cells isolated by MACS (Miltenyi Biotech). Lineage specific differentiation was achieved by culture in IMDM, 10\% FCS for 10 days in the presence of 25 $\mathrm{U} / \mathrm{ml} \mathrm{SCF}, 100 \mathrm{U} / \mathrm{ml}$ GM-CSF and $200 \mathrm{U} / \mathrm{ml} \mathrm{G-CSF}$ for myeloid cells and for 12 days in the presence of $25 \mathrm{U} / \mathrm{ml} \mathrm{SCF}, 2 \mathrm{U} / \mathrm{ml}$ erythropoietin and $500 \mathrm{nM}$ dexamethasone for erythroid cells. 


\section{Monitoring differentiation state}

Cell morphology was assessed by staining cytospun cells with May-Gruenwald / Giemsa with the inclusion of o-dianidisine to identify haemaglobinised cells. The frequency of clonogenic cells, capable of continued self-renewal in high interleukin 3 was measured by seeding 1000 cells in $3 \mathrm{ml}$ of methylcellulose self-renewal medium into each well of a 6 -well plate $[5,6]$. Plates were incubated at $37^{\circ} \mathrm{C}, 5 \% \mathrm{CO}_{2}$ in humidified air for 14 days before counting the number of visible colonies, all of which have undifferentiated morphology.

The following antibodies were used for FACS analysis: CD11b-APC (BioLegend); Ter-119FITC (BioLegend); CD117-PE-Cy7 (BD Pharmingen) and anti-Sca-1-PE (BD Pharmingen). FACS analysis was performed using a BD LSR II flow cytometer and BD FACSDiva Software, version 6.1.3.

\section{Isolation of mitochondria}

Mitochondria were isolated by hypotonic lysis, dounce homogenization, preclearing by centrifugation and then separation over a sucrose step gradient [7]. See supporting information for details.

\section{Capillary isoelectric focusing immunoassay}

The analysis of equal portions of each interface fraction was performed on a NanoPro 1000 instrument (proteinsimple, San Jose, CA) according to the manufacturer's instructions. Mouse-anti-ATP-synthase (Life technologies, 1:25) was used as the primary antibody, followed by an anti-mouse-biotin secondary antibody and streptavidin-HRP (proteinsimple, $1: 100)$

\section{iTRAQ labeling}

Pellets of the mitochondria-enriched interface fraction were resuspended in lysis buffer $(0.5$ M triethyl ammonium bicarbonate, $0.05 \%$ SDS, protease inhibitor cocktail 1:100, Sigma 
P8340) on ice for $30 \mathrm{~min}$. Lysates were centrifuged at $17,400 \mathrm{~g}$ for $10 \mathrm{~min}$ at $4{ }^{\circ} \mathrm{C}$ and the supernatant was recovered for subsequent reduction and cysteine blocking (ABSciex iTRAQ kit) before trypsin digestion at $37^{\circ} \mathrm{C}$ overnight. Samples were then vacuum dried and labelled using an iTRAQ 8plex kit (ABSciex) according to the manufacturer's instructions. Samples were labelled with the following isobaric tags: SR (self-renewing: 113 and 118); M3 (myeloid day 3: 114 and 119); E3 (erythroid day 3: 115 and 121); M6 (myeloid day 6: 116) and E6 (erythroid day 6: 117). Labelling efficiency (>95\%) and peptide quantification of the samples (area under the curve of the total ion current) were determined by LC-MS/MS analysis. Adjusted volumes were pooled to create a mixture containing equal amounts of total peptide from each condition. The E3 sample carrying the 115 tag had a peptide yield significantly lower than the other samples and was excluded from further analysis.

\section{Sample fractionation}

The final sample was fractionated off-line using an Agilent Zorbax extend C18 reversedphase chromatography column $(3.5 \mu \mathrm{m}, 4.6 \mathrm{~mm} \times 15 \mathrm{~cm})$, running a gradient from $99.5 \%$ high $\mathrm{pH}$ buffer $\mathrm{A}\left(0.1 \% \mathrm{NH}_{4} \mathrm{OH}\right.$ to $\left.\mathrm{pH} 10.5\right) / 0.5 \%$ high $\mathrm{pH}$ buffer $\mathrm{B}(99.9 \%$ acetonitrile, $0.1 \%$ $\mathrm{NH}_{4} \mathrm{OH}$ ), to $60 \%$ buffer $\mathrm{A} / 40 \%$ buffer $\mathrm{B}$ over 40 minutes at $700 \mu \mathrm{l} / \mathrm{min}$.

\section{ITRAQ mass spectrometry}

Peptide fractions were loaded onto a U3000 DIONEX C18 PepMap trap (3 $\mu \mathrm{m}, 180 \mu \mathrm{m} \times 20$ $\mathrm{mm}$ ) with a flow of $5 \mu \mathrm{l} / \mathrm{min}$ of $3 \%[\mathrm{v} / \mathrm{v}]$ acetonitrile, $0.1 \%[\mathrm{v} / \mathrm{v}]$ formic acid and $20 \mathrm{mM}$ citric acid for 5 minutes. Analytical separation was performed using a PepMap C18 Column (1.7 $\mu \mathrm{m}, 75 \mu \mathrm{m} \times 500 \mathrm{~mm})$. Peptides were separated over a 91 minute solvent gradient from $3 \%$ acetonitrile / $0.1 \%$ formic acid to $40 \%$ acetonitrile / $0.1 \%$ formic acid on-line to a LTQ Orbitrap Velos.

Data were acquired using an information-dependent acquisition (IDA) method where, for each cycle, one full MS scan of m/z 400 - 2000 was acquired in the Orbitrap at a resolution of 60,000 at $\mathrm{m} / \mathrm{z} 400$ with an automatic gain control (AGC) target of 106 . The 10 most intense 
ions were selected for higher-energy collisional dissociation and MS/MS analysis in the Orbitrap with a resolution of 7500 . Selected ions were excluded from further analysis for 60 seconds. lons with an unassigned or +1 charge were rejected.

\section{Bioinformatics and data analysis}

Data was analysed using Proteome Discover version 1.3 against the Mus musculus UniProt database. The search was set up as a mascot with $10 \mathrm{ppm}$ MS tolerance and $0.1 \mathrm{Da}$ MS/MS. The false discovery rate for protein identification was below $1 \%$ as calculated by Proteome discoverer. The MS proteomics data have been deposited to the ProteomeXchange Consortium [8] via the PRIDE partner repository with the dataset identifier PXD002968.

\section{Western Blotting}

Proteins were blotted from a $12 \%$ polyacrylamide gel to nitrocellulose and probed with an affinity purified rabbit anti Gpt2 antibody (Sigma AV48996) or anti-Tomm20 monoclonal (clone 4F3, Sigma), followed by peroxidase-labelled secondary antibodies and detection by chemiluminescence. Whole transferred protein was visualized by Ponceau staining.

\section{Metabolite assays}

FDCP-Mix cells from the various stages of differentiation were washed and seeded at $10^{6}$ per $\mathrm{ml}$ in fresh medium. Two independent experiments were performed, each with 5 replicates per condition. $18 \mathrm{hr}$ culture-conditioned media were snap frozen and stored at $-80{ }^{\circ} \mathrm{C}$. Glucose was measured using the Glucose liquicolor kit (Human $\mathrm{GmbH}$, Wiesbaden), lactate with a photometric assay [9], glutamine using a photometric assay [10] and glutamate using a published amino acid / acyl carnitine LC-MS/MS assay [11]. The changes in absolute metabolite concentration were calculated in comparison to control supernatants prepared from triplicate samples of cell-free media that had undergone the same experimental 
procedures. Mean and standard deviation were calculated $(n=10)$. An independent twosample t-test was performed and statistical significance was defined as $p<0.05$.

\section{Results}

\section{Cell differentiation and the preparation of mitochondria}

When cultured in myeloid or erythroid differentiation medium, FDCP-Mix cells typically undergo a period of proliferative differentiation lasting 5-7 days, followed by post-mitotic maturation [5,6]. To access changes associated with early differentiation, we chose to compare cells in the undifferentiated self-renewing state (SR) with those following 3 and 6 days of culture under myeloid (M3, M6) or erythroid (E3, E6) differentiation conditions. Analyses were carried out on unsorted populations in order firstly to minimise the manipulations and possible effects on metabolic activity and secondly to include any changes that may occur before alterations in surface marker expression. Final cell yields were between $7 \times 10^{7}$ and $3 \times 10^{8}$ cells per sample.

The changes in morphology of the FDCP-Mix cells undergoing myeloid or erythroid differentiation are shown in Fig.1. The self-renewing population comprises mostly small, "blast-like" cells, although occasional larger cells of myeloid phenotype are also present $[5,6]$. Under myeloid differentiation conditions the nuclear/cytoplasm ratio decreased and the first granulocytes and monocytes became recognisable by day 3. By day 6 the population consisted almost entirely of neutrophilic granulocytes and monocytes/macrophages. Under erythroid conditions, the decrease in nuclear/cytoplasm ratio over the first three days was less pronounced. Early erythroblasts appeared over this period with large nuclei, condensed chromatin and basophilic cytoplasm. Haemoglobinised cells and enucleated erythrocytes were detectable by day 3 and their frequency increased to day 6 . Flow cytometric analysis confirmed a background level of expression of the myeloid marker CD11b under selfrenewing conditions, increasing 10 fold over the 6 day differentiation culture under myeloid conditions with no detectable expression of the erythroid marker Ter-119. Under erythroid conditions, Ter-119 expression was detectable by day 3 and accumulated up to day 6 , at 
which point $30 \%$ of the cells were positive. Two subpopulations were present, expressing either no or high CD11b. Of the cells expressing high CD11b, less than $1 \%$ expressed Ter119. These measurements confirmed that, while the myeloid differentiation cultures are effectively free from erythroid cells, there is a background of myeloid differentiation under the erythroid differentiation conditions [5].

Clonogenicity assays confirmed that the proportion of cells retaining the capacity for independent self-renewal lay within the $2-5 \%$ range typical for FDCP-Mix maintained in high IL-3. The frequency of colony-forming cells decreased rapidly under erythroid conditions, but was maintained or increased up to day 3 in the myeloid conditions, decreasing sharply thereafter (Figure 1). It is unclear whether the transient increase following transfer to myeloid differentiation medium reflects a true increase in self-renewal activity, enrichment due to death of non-clonogenic cells or increased resistance to the physical stress of the colony assay.

The details of mitochondrial enrichment over sucrose gradients are provided under supplementary information.

\section{Mass spectrometry and data analysis}

Liquid chromatography tandem mass spectrometry (LC-MS/MS) of ITRAQ labeled peptides was used to determine relative protein abundance in the mitochondria-enriched fractions. A total of 2168 proteins were identified in the entire data set. Of these, we excluded 17 for which no relative quantification was available and 22 with unacceptable reliability scores below 20. The remaining ratios in the two control sets (SR: 118/113, M3: 119/114) were merged and a pooled $95 \%$ confidence interval $(\mathrm{Cl}, 0.562$ to 1.778$)$ used to set cut-off limits defining changes in expression in the subsequent pairwise comparisons. A total of 231 proteins for which either or both of the SR/SR and M3/M3 ratios exceeded either the respective $95 \% \mathrm{Cl}$ range (SR 118/113: M3 0.513 to $1.950,119 / 114: 0.628$ to 1.591 ) or the pooled cut-off limit were excluded from further analysis. Changes were defined as such only when the ratio lay outside this range for both available ratios in the comparisons M6/SR, 
$\mathrm{E} 3 / \mathrm{SR}, \mathrm{E} 6 / \mathrm{SR}$ and $\mathrm{E} 3 / \mathrm{M} 3$, for at least two ratios having a different divisor in the comparison M3/SR (four ratios available) or for the single available ratio in E6/M6. This list of 443 proteins was reduced further by excluding proteins for which (i) information was derived from data on less than 3 peptides or a ratio count $<3$ or (ii) the ratio variability between peptides representing the same protein exceeded $60 \%$.

This procedure generated a stringent set of 119 high-confidence "changing proteins". Of these, 30 register as changes only in direct comparison between the myeloid and erythroid lineages ( $1 \mathrm{M} 3 / \mathrm{E} 3$ and $29 \mathrm{M} 6 / \mathrm{E} 6)$. Further analysis was focussed on the remaining 89 proteins changed relative to the self-renewing population. Figure 2 shows the number of such changes detected at each stage of differentiation culture.

The list of corresponding proteins together with accession numbers, mean iTRAQ ratios and a brief description of function is available as supplementary table 1 . Thirty-seven of these 89 proteins are located in or associated with mitochondria according to the DAVID bioinformatics Functional Annotation Tool version 6.7 [12,13] (tag "mitochondrion" in GOTERM_CC_FAT, last checked November 27 2016). The remaining 52 proteins tend to be associated with endoplasmic reticulum, plasma membrane or vesicles, suggesting membrane contamination of the mitochondrial-enriched fraction. We therefore focused exclusively on the 37 mitochondrial proteins, the expression patterns of which are shown in more detail in Fig. 3.

\section{Proteins increasing during differentiation}

Ten proteins registered an increase during myeloid differentiation only (Fig. 3A) and a further 2 during both myeloid and erythroid differentiation (Fig. 3B). Five of these 12 proteins (Gsr, Ethe1, Prdx5, Msra and Mpst) have antioxidant function, suggesting that the differentiating neutrophilic granulocytes are either preparing for or reacting to the oxidative stress associated with their function. A further 6 (Echs1, Clyb1, Ak4, Ndufv3, Hmgcl, and Hk1) are involved in various reactions of core metabolism, although at first analysis there is no obvious connection between them. The only mitochondrial protein to accumulate to similar 
high levels in both lineages, 3-mercaptopyruvate sulfur transferase (Mpst), is an antioxidant protein of the inner mitochondrial membrane involved in cysteine degradation and the detoxification of cyanide.

Six mitochondria-associated proteins increased above the threshold level during erythroid differentiation but show very little change during myeloid differentiation (Fig. 3C). Two of the most strongly induced, ferrochetalase (Fech) and protoporphyrin oxidase (Ppox), are involved in heme synthesis. Two others, acyl coA synthetase (Acss1) and sterol carrier protein 2 (Scp2), mediate the synthesis and transfer of cholesterol, which is present at high concentration in erythrocyte membranes [14]. Catalase (an antioxidant already known to be highly expressed in erythrocytes) and Ap2m1 (an ATPase proton pump subunit of unclear significance) accumulated to modest levels.

\section{Proteins decreasing during differentiation}

Nineteen proteins decreased during differentiation, 17 of which tended to decrease in both lineages, even though the cut-off may only have been reached in one. Eight such proteins (Ndufs4, Uqcrc1, Uqcrc2, Ndufa10, Etfdh, Uqcrfs1, ATP5a1 and Atp5h) are electron transport chain or ATP synthase subunits and a further 3 (Hccs, Nnt, and Gdp2a) have functions closely related to electron transport. This, together with the down-regulation of carnitine palmitoyl transferase (Cpt1a), indicates that shifting FDCP-Mix cells to differentiation conditions results in a decrease in oxidative phosphorylation in general and in B oxidation of fatty acids in particular. All of the remaining 5 proteins that decrease in both lineages (Tomm70a, Abcb7, Vdac2, Sfxn1 and Timm50) have channel or transporter function.

Two mitochondrial proteins stand out as decreasing in a lineage-specific manner. One of these, the ATP-binding cassette transporter Abcf2, is a mitochondrial transporter of unknown function that clearly decreases only under myeloid differentiation conditions. In contrast, the mitochondrial glutamate pyruvate transaminase Gpt2 (EC 2.6.1.2) was depleted during 
erythroid but not myeloid differentiation. Gpt2 transfers the amino group between glutamate (to generate alpha-ketoglutarate) and pyruvate (to generate alanine). Since the specific decrease of Gpt2 during erythroid differentiation suggests lineage-specific changes in the balance of glutamine metabolism, this change was chosen for validation by western blotting. Decreased Gpt2 protein levels in erythroid compared to myeloid cells were confirmed using independent differentiation cultures of FDCP-Mix and of human CD34 ${ }^{+}$progenitor cells (Fig. 4). Expression in the human cells was compared to that of Tomm20 as a mitochondrial internal control that had consistently showed no change in the ITRAQ analyses. Having thus confirmed the change in Gpt2 levels, we then looked for direct evidence of a lineage-specific change in glutamine metabolism by measuring the glutamine and glutamate levels in medium conditioned by FDCP-Mix cells at various stages of differentiation. Glucose and lactate levels were determined in parallel as an indicator of glycolytic activity (Fig. 4).

The uptake of glutamine was comparable in differentiating myeloid and erythroid populations. However, the erythroid cells released large amounts of glutamate, while the myeloid cells did not. This pattern is consistent with an inability of the erythroid cells to introduce glutamate into the TCA cycle via the Gpt2-mediated transamination reaction. The biochemical assay therefore provides functional confirmation of the substantial reduction in Gpt2 activity in the erythroid lineage. Glucose uptake was found to increase during early myeloid differentiation and to decrease during erythroid differentiation. Lactate release essentially mirrored glucose uptake, suggesting that, while the extent of glucose catabolism may vary between the lineages (consistent with the increase in $\mathrm{Hk}_{1}$ seen in the myeloid lineage, Fig. 3B), the proportion of glucose being routed through glycolysis remains largely unchanged.

\section{Discussion}

The aim of this study was to identify hematopoietic lineage- and/or stage-specific changes in the expression level of proteins involved in core metabolism by proteomic analysis of 
mitochondria prepared from various stages of erythroid and myeloid differentiation of a multipotent murine progenitor cell line.

Our results show a high degree of overlap with those of a previous whole-cell proteomics analysis of primary hematopoietic cell populations [15], with 13 of the 37 high-confidence mitochondrial proteins identified here also having been found to be differentially expressed in primary stem and progenitor cell populations. Furthermore, the 52 "non-mitochondrial" proteins identified in FDCP-Mix but excluded from the initial analysis also show the bias towards translation and cytoskeletal functions noted in the primary cell study [15], see supplementary table 1.

The overlap with the primary cell analysis, together with our detection of mitochondrial proteins with known roles in erythrocyte or granulocyte function, supports the relevance of the FDCP-Mix model system. However, the changes of most interest are clearly those that were previously unknown. Five of the 17 mitochondrial proteins down-regulated during differentiation along both lineages have channel or transporter function, suggesting that metabolite transport into and out of the mitochondria may be a key level of regulation during differentiation. The expression of VDAC2 in particular closely follows the frequency of the colony forming cells with the highest self-renewal capacity. VDACs are porin-like transporters for small metabolites that respond to membrane potential and their inhibition blocks the proliferation of ras transformed cells [16] (Yagoda et al., 2007). Furthermore, the related protein VDAC3 was found to be over-represented in primary multipotent progenitors and down-regulated in committed myeloid progenitors [15], so it will be interesting to determine whether VDAC activity is causally associated with self-renewal.

One of the most striking findings was the consistent decrease in electron transport chain (ETC) protein levels during differentiation along both myeloid and erythroid lineages. In addition to the 8 ETC (and 3 associated) proteins that were flagged as high-confidence changes, targeted re-analysis of the data revealed a total of 48 ETC components in the complete data set, most of which follow a similar (if less extreme) pattern of expression (not shown). The reduction in CPT1 over this same period suggests that the self-renewing state 
of FDCP-Mix draws energy primarily from oxidative phosphorylation of acetyl CoA derived from the $B$ oxidation of fatty acids. This is consistent with an increasing body of evidence connecting fatty acid oxidation (FAO) with homeostatic self-renewal $[2,17]$.

If energy production from FAO decreases during commitment and differentiation, it seems likely that the proliferative differentiation process uses alternative energy sources. Glycolysis, measured by glucose uptake and lactate release, was particularly high during the early proliferative phase of myeloid differentiation. We also detected a strong increase in HK1 in the myeloid lineage and although it must be borne in mind that the mitochondria-associated hexokinase proteins detected here are not necessarily a reliable indicator of total cytoplasmic glycolysis, these observations suggest that glucose does become a major substrate in cells undergoing myelopoiesis. It is possible that glucose-derived acetyl CoA is also used to drive the TCA cycle. However, there were myeloid-specific increases in a number of other mitochondrial enzymes that either use or generate acetyl CoA: Enoyl CoA hydratase (Echs1; B-oxidation of fatty acids); citrate lyase (Clyb1; malate synthesis) and 3-hydroxy-3methylglutaryl-coenzyme A lyase ( $\mathrm{Hmgcl}$; ketone body metabolism). This suggests that acetyl CoA flux may change significantly during myelopoiesis and may be a particularly informative focus for further studies.

There was no increase in glycolysis during erythroid differentiation. However, the degree of FDCP-Mix proliferation during erythroid differentiation is far lower than that during myeloid differentiation, so there is insufficient evidence to conclude a difference in anabolic glycolytic flux between the two lineages. What does stand out during erythroid differentiation is the specific down-regulation of the enzyme glutamine pyruvate transaminase 2 (Gpt2) suggesting a decreased capacity for glutaminolysis that we were able to confirm by direct measurement of glutamine uptake and glutamate release. This raises questions concerning the role of glutamine in erythropoiesis. Firstly, it cannot be ruled out that the FDCP-Mix cells experience an artefactual block in glutaminolysis that limits proliferation. Indeed, it has recently been reported that the glutamine transporter ASCT2 is essential for erythropoiesis, and that erythroid progenitors use exogenous glutamine for nucleoside synthesis [18]. 
However, the fact that these cells express glutamine synthase, and that at least some progenitors can undergo erythropoiesis in the absence of glutamine [18] suggests that the situation is probably more complex.

This highlights an important consideration in analyses of metabolic activity in cultured cells, in that key features of cellular metabolism may become apparent only in the specialized nutrient environment of the appropriate niche. Our use of reduced oxygen conditions is one step in this direction. However, in following up the findings reported here it may be necessary to progressively adapt the culture conditions to reflect more accurately the (still unknown) physiological micro-environment of the respective in vivo niche.

In summary, we have succeeded in identifying differences in the metabolism of FDCP-Mix cells undergoing self-renewal versus myeloid and erythroid differentiation. Our work identifies potentially important changes in fatty acid oxidation, glucose and glutamine metabolism, and suggests extensive changes at the level of transport across the mitochondrial membrane. Further analysis of these changes should lead to a better understanding of the role played by metabolism in haematopoiesis, and enable us to establish more realistic and more effective culture conditions for the amplification or lineage specific haematopoietic differentiation of stem and progenitor cells.

\section{Acknowledgements}

We gratefully acknowledge the technical support provided by the IZKF FACS core unit at the University of Leipzig. This work was supported by EU FP7 grant 229328 (Redontap) to MC and by Bloodwise support for ADW. The authors would like to thank Andrew Pierce for critical reading and constructive comments on the manuscript.

The authors have declared no conflicts of interest. 


\section{References}

[1] Suda, T., Takubo, K., Semenza, G.L. Metabolic regulation of hematopoietic stem cells in the hypoxic niche. Cell Stem Cell 2011 9, 298-310.

[2] Ito, K., Carracedo, A., Weiss, D., Arai, F. et al. A PML-PPAR-delta pathway for fatty acid oxidation regulates hematopoietic stem cell maintenance. Nat. Med. 2012, 18, 1350-1358.

[3] Robinson, J.M. Phagocytic leukocytes and reactive oxygen species. Histochem. Cell Biol. 2009, 131, 465-469.

[4] Siems, W.G., Sommerburg, O., Grune, T. Erythrocyte free radical and energy metabolism. Clin. Nephrol. 2000, 53, S9-S17.

[5] Heyworth, C.M., Alauldin, M., Cross, M.A., Fairbairn, L.J., Dexter, T.M., Whetton, A.D. Erythroid development of the FDCP-Mix A4 multipotent cell line is governed by the relative concentrations of erythropoietin and interleukin 3. Br. J. Haematol. 1995, 91, 15-22.

[6] Spooncer, E., Heyworth, C.M., Dunn, A., Dexter, T.M. Self-renewal and differentiation of interleukin-3-dependent multipotent stem cells are modulated by stromal cells and serum factors. Differ. Res. Biol. Divers. 1986, 31, 111-118.

[7] Darley-Usmar, V.M., Rickwood, D., Wilson, M.T. Mitochondria: a practical approach. IRL Press, Oxford 1987.

[8] Vizcaíno, J.A., Deutsch, E.W., Wang, R., Csordas, A., et al. ProteomeXchange provides globally coordinated proteome data submission and dissemination. Nat. Biotechnol. 2014,32(3), 223-226

[9] Dringen, R., Gebhardt, R., Hamprecht, B. Glycogen in astrocytes: possible function as lactate supply for neighboring cells. Brain Res. 1993, 623, 208-214.

[10] Lund, P. L-Glutamine and L-glutamate: UV-method with glutaminase and glutamate dehydrogenase. In Burgmeyer, U. (ed) Methods of Enzymatic Analysis, Academic Press, New York, 1986, pp. 357-363.

[11] Brauer, R., Leichtle, A.B., Fiedler G.M., Thiery, J., Ceglarek, U. Preanalytical standardization of amino acid and acylcarnitine metabolite profiling in human blood using tandem mass spectrometry. Journal of Metabolomics 2011,7, 344-352. 
[12] Huang, D.W., Sherman, B.T., Lempicki, R.A. Systematic and integrative analysis of large gene lists using DAVID bioinformatics resources. Nat. Protoc. 2009, 4, 44-57.

[13] Huang, D.W., Sherman, B.T., Lempicki, R.A. Bioinformatics enrichment tools: paths toward the comprehensive functional analysis of large gene lists. Nucleic Acids Res. 2009, $37,1-13$.

[14] Yeagle, P.L. Cholesterol and the cell membrane. Biochim. Biophys. Acta 1985, 822, 267-287.

[15] Klimmeck, D., Hansson, J., Raffel, S., Vakhrushev, S.Y., et al. Proteomic Cornerstones of Hematopoietic Stem Cell Differentiation: Distinct Signatures of Multipotent Progenitors and Myeloid Committed Cells. Mol. Cell. Proteomics 2012, 11, 286-302.

[16] Yagoda, N., von Rechenberg, M., Zaganjor, E., Bauer, A.J. et al. RAS-RAF-MEKdependent oxidative cell death involving voltage-dependent anion channels. Nature 2007, 447, 864-868.

[17] Kohli, L., Passegue, E. Surviving change: the metabolic journey of hematopoietic stem cells. Trends Cell Biol. 2014, 24, 479-487.

[18] Oburoglu, L., Tardito, S., Fritz, V., de Barros, S.C. et al. Glucose and Glutamine Metabolism Regulate Human Hematopoietic Stem Cell Lineage Specification. Cell Stem Cell $2014,15,169-184$. 


\section{Figure Legends}

Figure 1. Changes in morphology, surface antigen expression and clonogenicity of differentiating FDCP-Mix cells

Stained preparations from FDCP-Mix cells cultured under self-renewal conditions (SR), and after 3 and 6 days of myeloid $(M 3, M 6)$ or erythroid $(E 3, E 6)$ differentiation are shown. Scale bars $50 \mu \mathrm{m}$. FACS analyses of CD11b and Ter-119 are shown to the right of each photograph with mean fluorescence intensities above (CD11b) and below (Ter-119). Vertical lines delineate the limits of isotype control staining. The clonogenicity is shown as mean, maximum and minimum of 2 to 4 replicate assays.

Figure 2. Number of protein changes seen 3 and 6 days after transfer from selfrenewal to differentiation conditions.

The total number of changes (98) exceeds the total number of changing proteins (89) because some proteins show changes in more than one comparison. The numbers in brackets show those proteins with a previously reported association to mitochondria.

Figure 3. The expression patterns of the 37 changing proteins previously described as mitochondrial associated.

The proteins are grouped according to the pattern of differentiation-associated changes. Data is shown as mean of the $2(\mathrm{M} 6, \mathrm{E} 3, \mathrm{E} 6$ to $\mathrm{SR})$ or 4 (M3 to SR) available iTRAQ ratios. Further details of the individual proteins are shown in supplementary table 1.

Figure 4. Confirmation of Gpt2 reduction during erythroid differentiation.

A-D: The changes in metabolite levels in media conditioned over 18 hours in the presence of FDCP-Mix cells at the various stages of differentiation. Data are presented as mean + or SD $(n=10),{ }^{*}$ indicates a significant change compared to SR $(p<0.05)$.

$\mathrm{E}$ : Western of FDCP-Mix. The numbers beneath the lanes indicate the strength of the Gpt2 signal normalised to the whole protein signal quantified by Ponceau staining (Pon). F 
Western blot of human myeloid (M) and erythroid (E) cells differentiated over 10 and 12 days from umbilical cord blood CD34+ progenitor cells. A FACS profile confirming the identity of these cells is shown in supplementary Figure 2. 
Figure 1. Changes in morphology, surface antigen expression and clonogenicity of differentiating FDCP-Mix cells
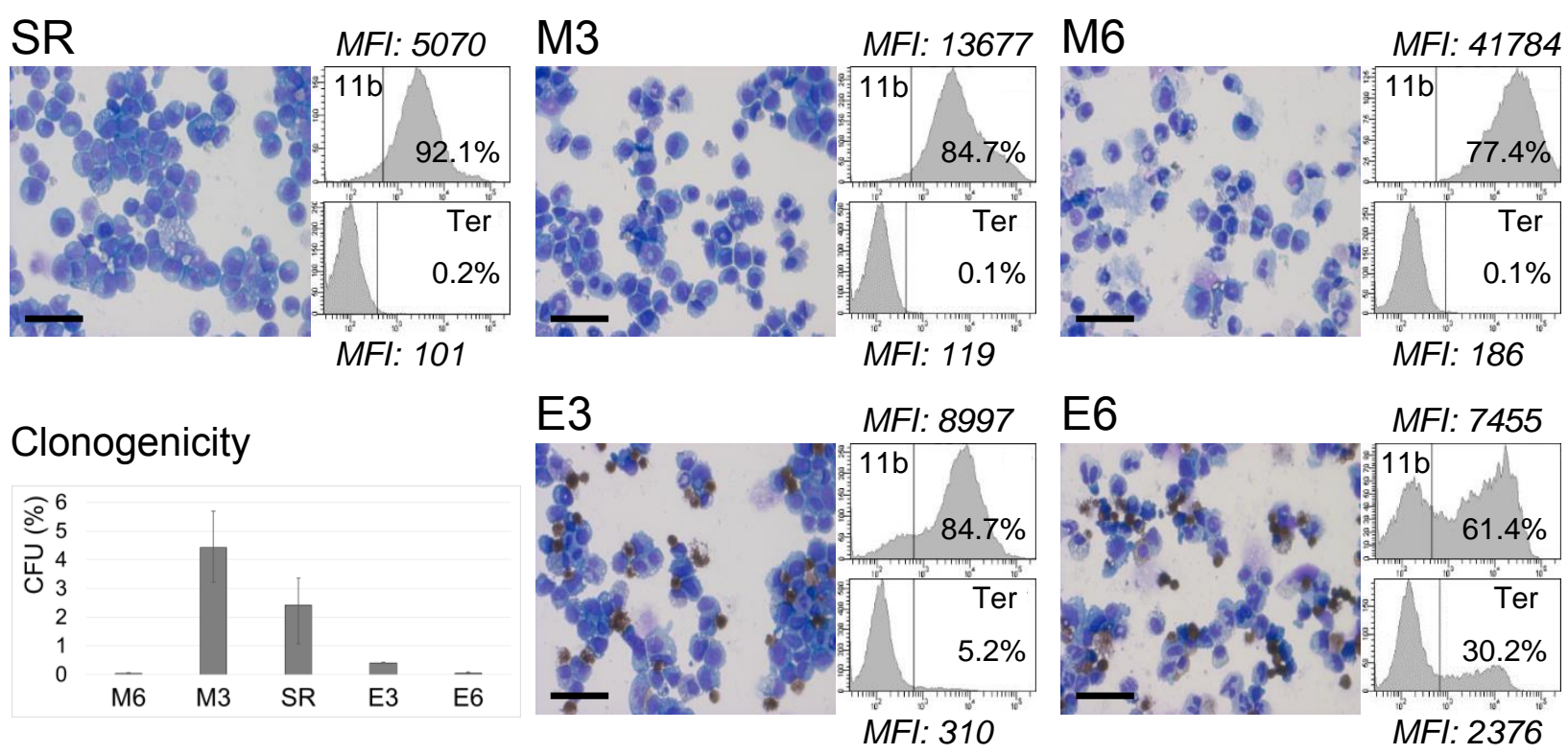

Figure 2. Number of protein changes seen 3 and 6 days after transfer from selfrenewal to differentiation conditions.

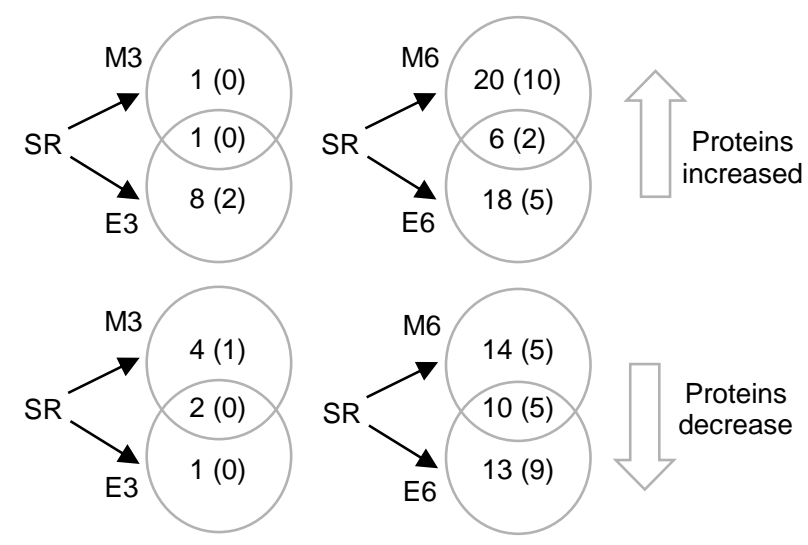


Figure 3. The expression patterns of the 37 changing proteins previously described as mitochondrial associated.

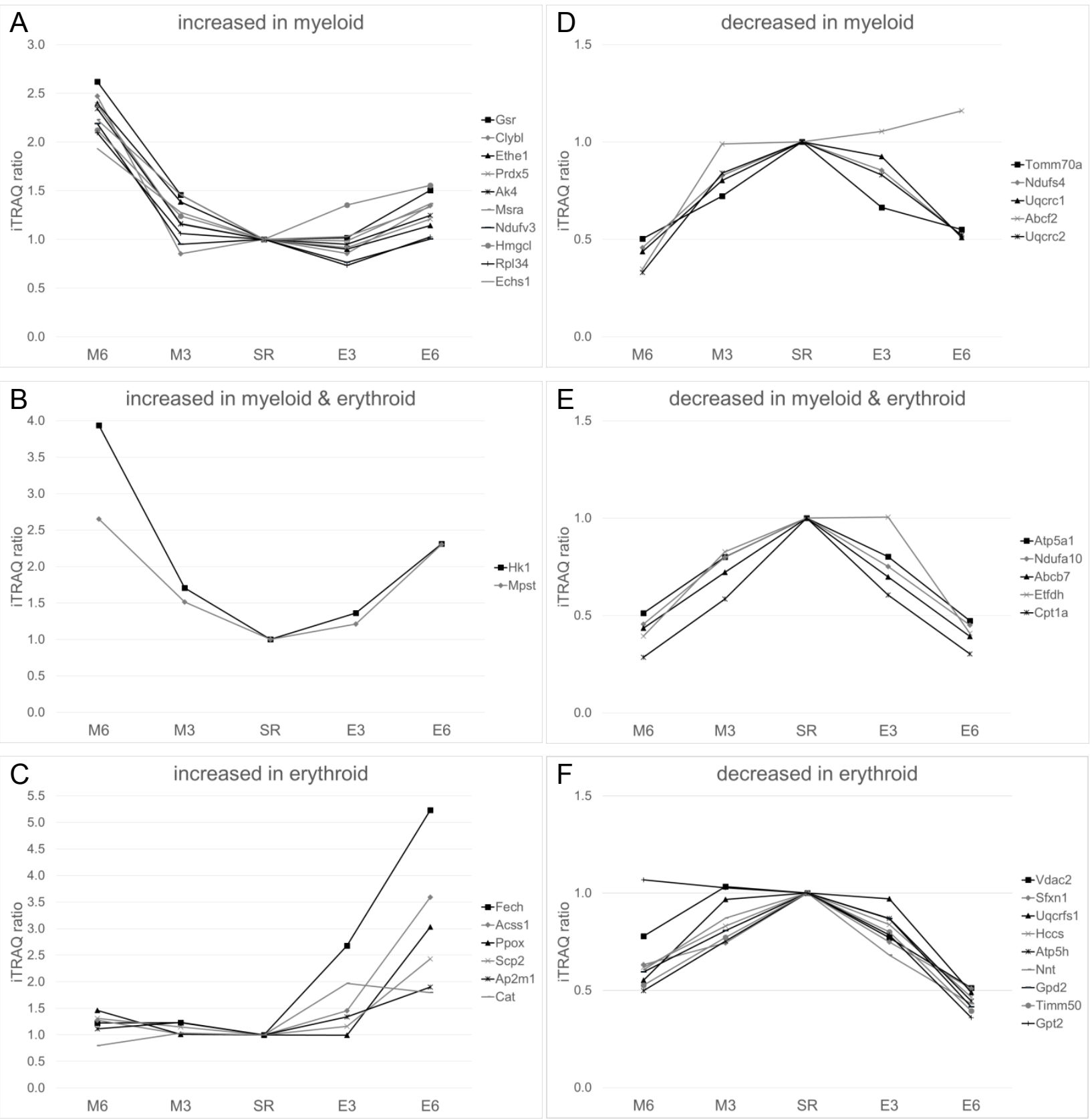


Figure 4. Confirmation of Gpt2 reduction during erythroid differentiation.

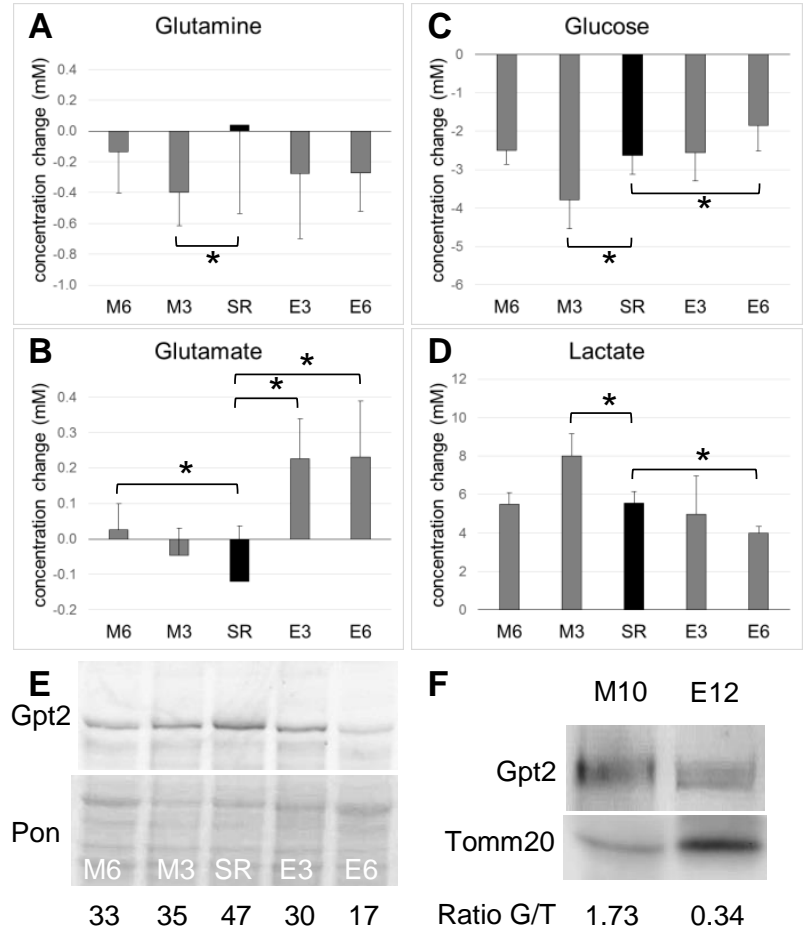


Supplementary Material

A

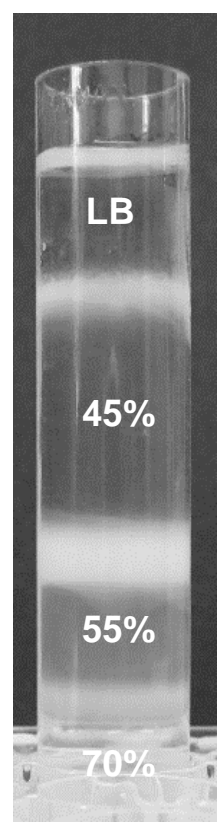

B

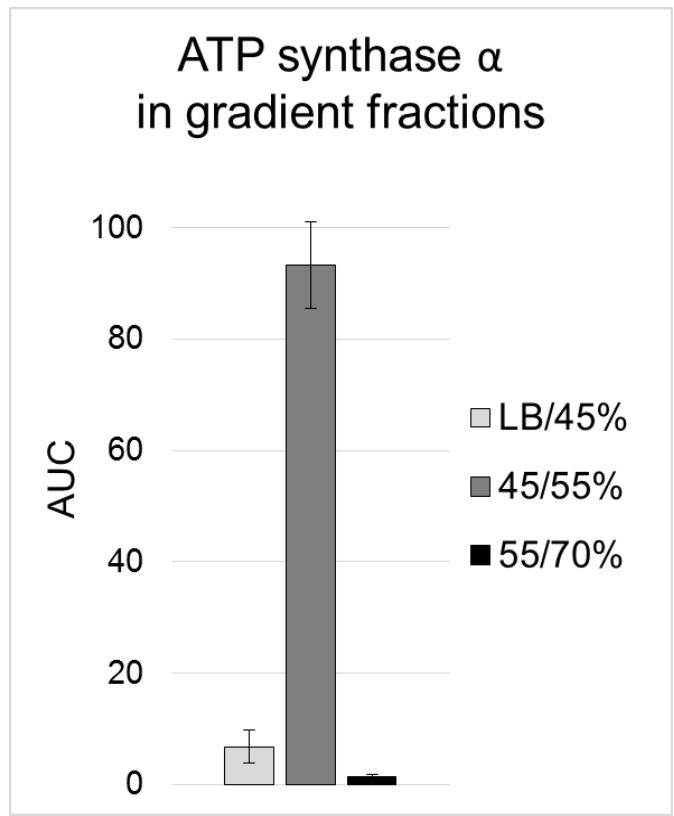

Supplementary Figure 1. Enrichment of mitochondria.

A: Sucrose gradient ultracentrifugation of a fraction pre-depleted of cytoplasmic and nuclear material. B: Isoelectric focusing immunoassay confirming enrichment of the mitochondrial protein ATP synthase subunit $\alpha$ at the interface between $45 \%$ and $55 \%$ sucrose. Data are presented as mean +/- SD (triplicate assay). LB: loading buffer. 

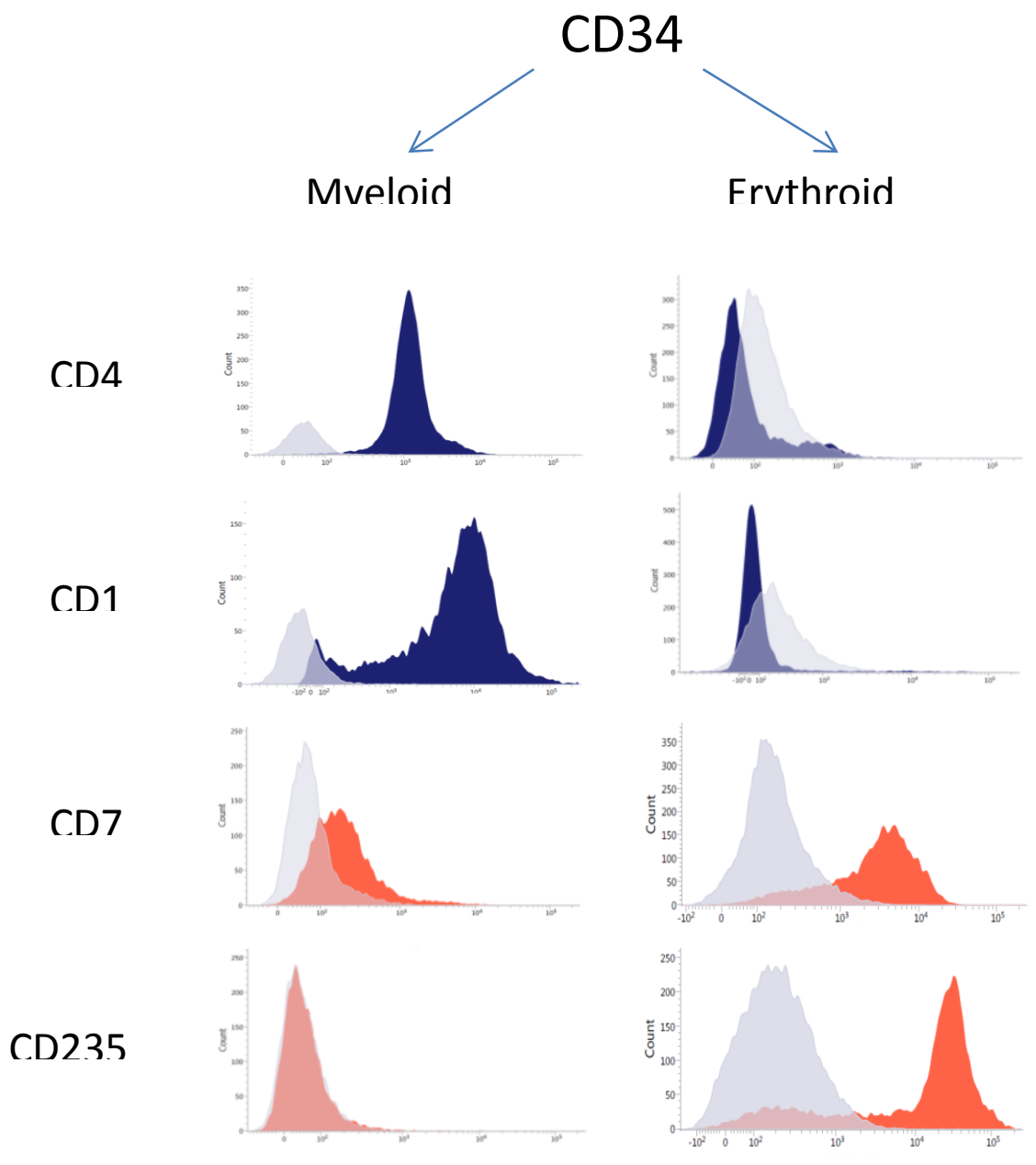

\section{Supplementary Figure 2.}

Human cord blood CD $34^{+}$progenitors were cultured under conditions supporting either myeloid or erythroid differentiation for 10 and 12 days respectively as described in Materials and Methods. FACS analyses confirmed that cells expanded under myeloid conditions expressed high levels of CD45 (pan-leukocyte) and CD13 (myeloid) markers shown in blue, but not of the erythroid antigens CD71 (transferrin receptor) and CD235a (glycophorin a) shown in red, while the cells expanded under erythroid conditions expressed the erythroid but not the leukocyte/myeloid markers. The grey underlay on each graph shows the appropriate isotype control. Cells were harvested at these time points for the western blotting shown in figure $4 \mathrm{~F}$ of the main manuscript. 
Supplementary Figure 3. The expression patterns of the 37 changing proteins previously described as mitochondrial associated.
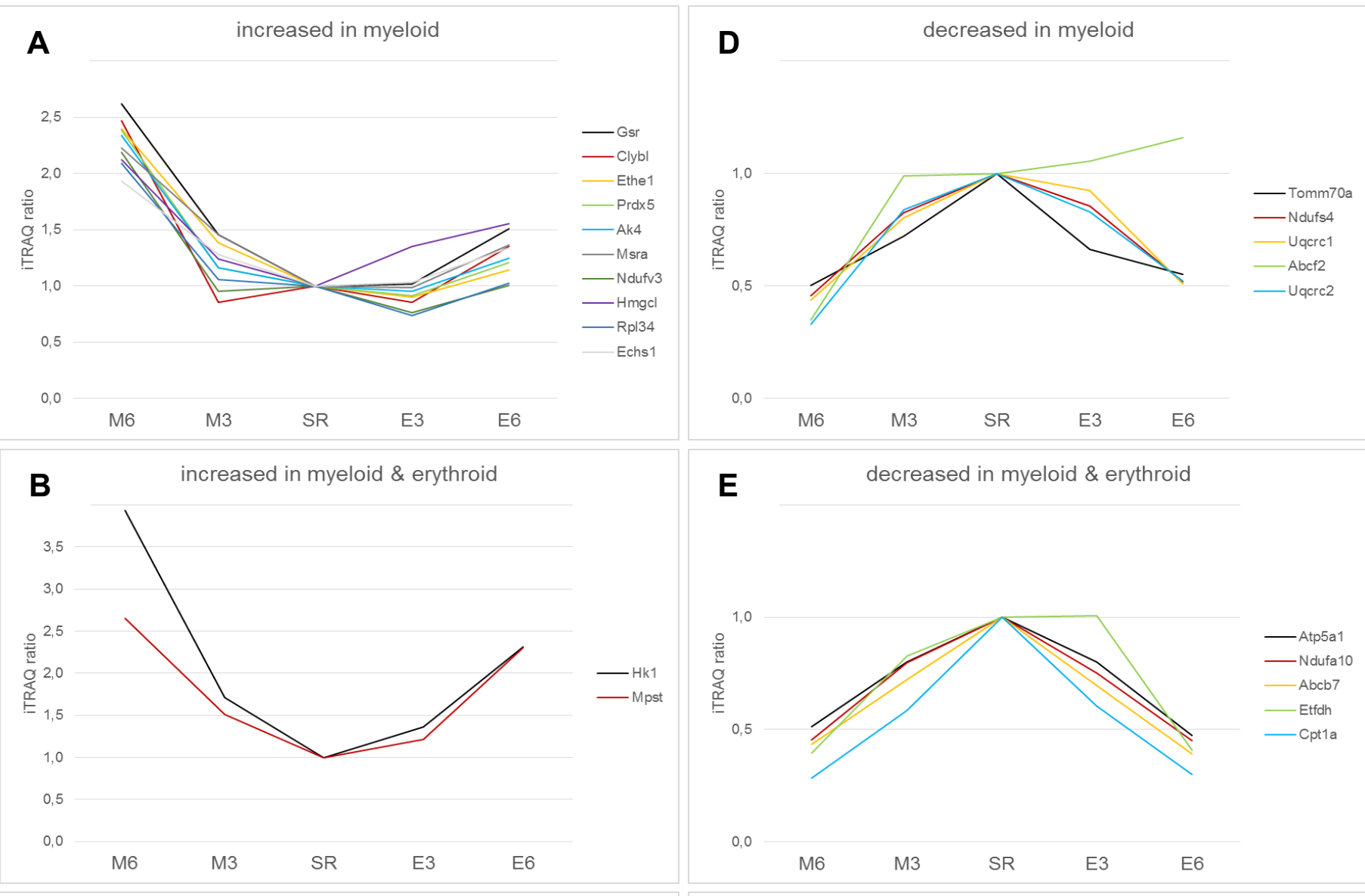

E decreased in myeloid \& erythroid
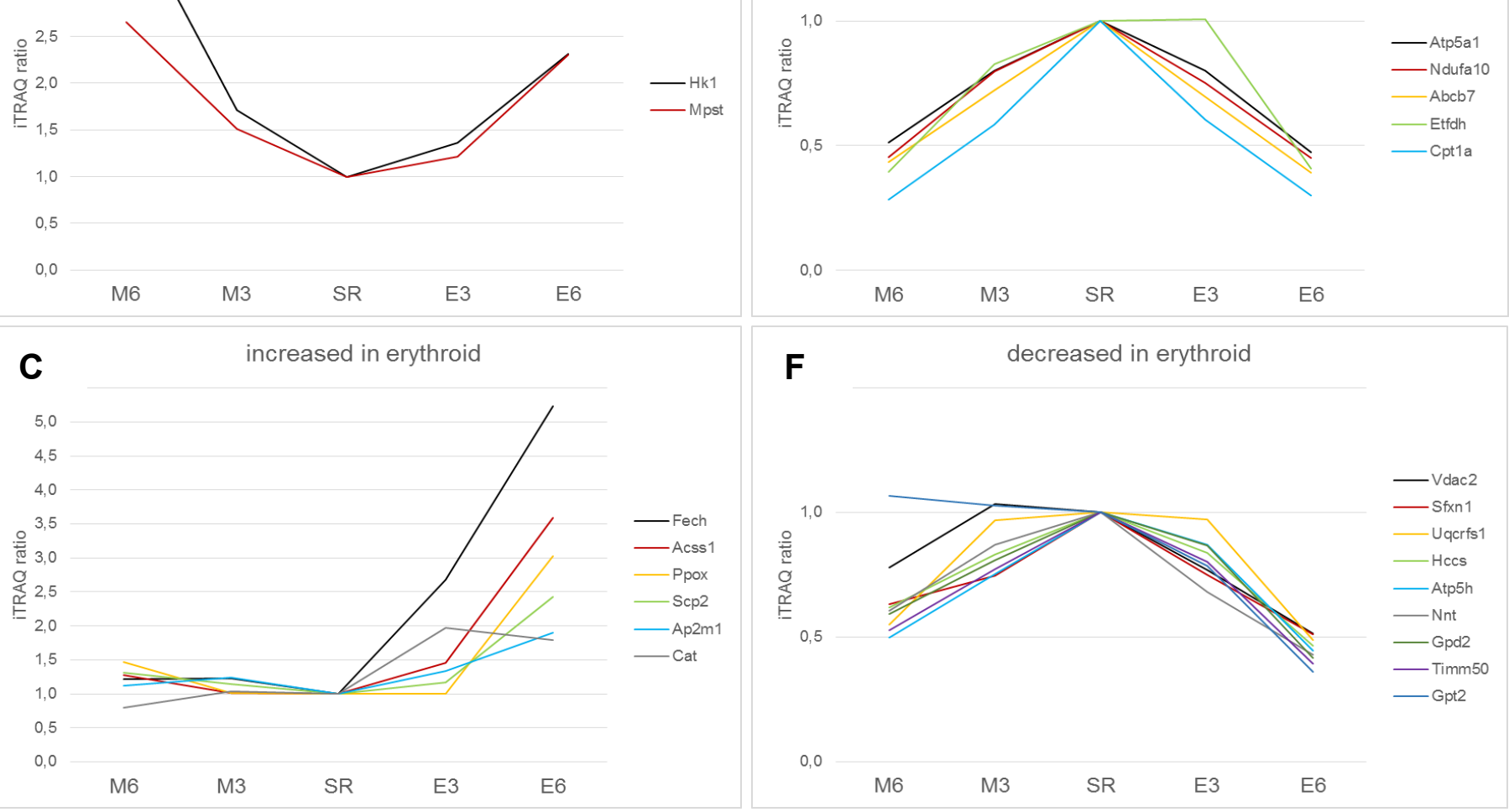


\section{Supplementary Table 1: 89 proteins differentially regulated between self- renewing and differentiating FDCP-mix.}

"M" in column 1 denotes those 37 proteins previously described to be associated with mitochondria.

Ratios lying below the lower or above the upper cut off and therefore registering as changes are shown in bold. Ratios above the cut-off range are highlighted in green and those below in red.

\begin{tabular}{|c|c|c|c|c|c|c|c|c|}
\hline & Acc $\mathrm{Nr}$ & Gene & Protein & Processes & M6 & M3 & E3 & E6 \\
\hline M & Q3U9R7 & Gsr & Glutathione reductase & $\begin{array}{l}\text { Protection against } \\
\text { oxidative stress }\end{array}$ & 2.620 & 1.456 & 1.016 & 1.506 \\
\hline M & Q8R4N0 & Clybl & $\begin{array}{l}\text { Citrate lyase subunit } \\
\text { beta-like protein }\end{array}$ & Malate synthesis & 2.471 & 0.852 & 0.856 & 1.349 \\
\hline $\mathrm{M}$ & Q9DCM0 & Ethe1 & $\begin{array}{l}\text { Persulfide } \\
\text { dioxygenase }\end{array}$ & $\begin{array}{l}\text { Hydrogen sulphide } \\
\text { detoxification }\end{array}$ & 2.397 & 1.386 & 0.899 & 1.143 \\
\hline M & Q3UWS9 & Prdx5 & Peroxiredoxin 5 & $\begin{array}{l}\text { Protection against } \\
\text { oxidative stress }\end{array}$ & 2.384 & 1.165 & 0.916 & 1.209 \\
\hline M & Q9WUR9 & Ak4 & Adenylate kinase 4 & NDP kinase & 2.341 & 1.160 & 0.950 & 1.245 \\
\hline $\mathrm{M}$ & Q91WK9 & Msra & $\begin{array}{l}\text { Mitochondrial peptide } \\
\text { methionine sulfoxide } \\
\text { reductase }\end{array}$ & $\begin{array}{l}\text { Protection against } \\
\text { oxidative stress }\end{array}$ & 2.230 & 1.456 & 0.987 & 1.367 \\
\hline M & Q3U4K3 & Ndufv3 & $\begin{array}{l}\text { NADH dehydrogenase } \\
\text { (ubiquinone) } \\
\text { flavoprotein } 3\end{array}$ & $\begin{array}{l}\text { Electron transport } \\
\text { chain }\end{array}$ & 2.188 & 0.951 & 0.765 & 1.004 \\
\hline M & Q3UMP2 & $\mathrm{Hmgcl}$ & $\begin{array}{l}\text { 3-hydroxy-3- } \\
\text { methylglutaryl- } \\
\text { Coenzyme A lyase }\end{array}$ & $\begin{array}{l}\text { Leucine } \\
\text { degradation } \\
\text { Ketone body } \\
\text { metabolism }\end{array}$ & 2.123 & 1.241 & 1.355 & 1.556 \\
\hline M & Q9D1R9 & Rpl34 & $\begin{array}{l}\text { 60S ribosomal protein } \\
\text { L34 }\end{array}$ & Translation & 2.094 & 1.059 & 0.734 & 1.026 \\
\hline M & Q8BH95 & Echs 1 & Enoyl-CoA hydratase & $\begin{array}{l}\text { Fatty acid } \\
\text { oxidation }\end{array}$ & 1.933 & 1.279 & 1.031 & 1.335 \\
\hline & A2A6J4 & Lsp1 & $\begin{array}{l}\text { Lymphocyte-specific } \\
\text { protein } 1\end{array}$ & Signalling & 3.122 & 0.806 & 0.926 & 0.887 \\
\hline & Q3U1U4 & Itgam & $\begin{array}{l}\text { Integrin alpha-M } \\
\text { (CD11b) }\end{array}$ & $\begin{array}{l}\text { Adhesion, } \\
\text { Signalling }\end{array}$ & 2.743 & 1.188 & 0.901 & 1.063 \\
\hline & Q5RKP0 & Vat1 & Vat1 protein & $\begin{array}{l}\text { Mitochondrial } \\
\text { fusion }\end{array}$ & 2.479 & 1.414 & 1.410 & 1.507 \\
\hline
\end{tabular}




\begin{tabular}{|c|c|c|c|c|c|c|c|c|}
\hline & Q3TN84 & P4ha1 & $\begin{array}{l}\text { Proline 4-hydroxylase } \\
\text { 1a }\end{array}$ & $\begin{array}{l}\text { Proline } \\
\text { modification }\end{array}$ & 2.271 & 0.585 & 0.466 & 1.089 \\
\hline & Q3UDF8 & Eif2s3x & $\begin{array}{l}\text { Eukaryotic translation } \\
\text { initiation factor } 2 \text {, } \\
\text { subunit } 3, x \text {-linked }\end{array}$ & Translation & 2.271 & 1.355 & 0.879 & 1.726 \\
\hline & P09103 & $\mathrm{P} 4 \mathrm{hb}$ & $\begin{array}{l}\text { Protein disulfide- } \\
\text { isomerase }\end{array}$ & $\begin{array}{l}\text { Protection against } \\
\text { oxidative stress }\end{array}$ & 2.316 & 1.018 & 0.814 & 1.119 \\
\hline & Q9ES97 & Rtn3 & Reticulon-3 & $\begin{array}{l}\text { Membrane } \\
\text { trafficking }\end{array}$ & 2.054 & 1.482 & 0.876 & 1.746 \\
\hline & P81117 & Nucb2 & Nucleobindin-2 & $\begin{array}{l}\text { Calcium } \\
\text { homeostasis }\end{array}$ & 2.031 & 0.714 & 0.548 & 1.299 \\
\hline & Q6ZWX6 & Eif2s1 & $\begin{array}{l}\text { Eukaryotic translation } \\
\text { initiation factor } 2 \\
\text { subunit } 1\end{array}$ & Translation & 2.002 & 1.295 & 1.011 & 1.609 \\
\hline & A2APX3 & Cst3 & Cystatin-C & Protease inhibitor & 1.999 & 1.140 & 1.150 & 0.943 \\
\hline$M$ & Q3TJE3 & $\mathrm{Hk} 1$ & Hexokinase 1 & Glycolysis & 3.938 & 1.708 & 1.364 & 2.313 \\
\hline M & Q3UW66 & Mpst & $\begin{array}{l}\text { Mercaptopyruvate } \\
\text { Sulfurtransferase }\end{array}$ & $\begin{array}{l}\text { Cyanide } \\
\text { detoxification }\end{array}$ & 2.653 & 1.515 & 1.213 & 2.303 \\
\hline & Q3U4V9 & Itgae & Integrin alpha E & $\begin{array}{l}\text { Adhesion, } \\
\text { Signalling }\end{array}$ & 1.311 & 2.410 & 2.031 & 1.923 \\
\hline & O88569 & Hnrnpa2b1 & $\begin{array}{l}\text { Heterogeneous } \\
\text { nuclear } \\
\text { ribonucleoproteins } \\
\text { A2/B1 }\end{array}$ & mRNA processing & 1.614 & 1.797 & 1.431 & 2.109 \\
\hline & O35479 & $\mathrm{Rbmx}$ & $\begin{array}{l}\text { RNA binding motif } \\
\text { protein, X-linked-like- } \\
1\end{array}$ & mRNA processing & 2.684 & 1.418 & 0.976 & 2.761 \\
\hline & P19253 & Rpl13a & $\begin{array}{l}\text { 60S ribosomal protein } \\
\text { L13a }\end{array}$ & Translation & 2.223 & 1.258 & 0.798 & 2.153 \\
\hline & Q3UBR5 & Ptbp1 & $\begin{array}{l}\text { Polypyrimidine tract } \\
\text { binding protein } 1\end{array}$ & mRNA processing & 2.078 & 1.539 & 0.875 & 2.549 \\
\hline & E9QLZ3 & Сyp4f18 & $\begin{array}{l}\text { Leukotriene-B(4) } \\
\text { omega-hydroxylase } 2\end{array}$ & $\begin{array}{l}\text { Leukotriene } \\
\text { catabolism } \\
\text { chemotaxis }\end{array}$ & 2.065 & 0.950 & 1.131 & 4.797 \\
\hline$M$ & Q8C3V7 & Fech & Ferrochelatase & Heme synthesis & 1.222 & 1.230 & 2.679 & 5.230 \\
\hline$M$ & Q3TZ45 & Acss1 & $\begin{array}{l}\text { Acyl-CoA synthetase } \\
\text { short-chain family } \\
\text { member } 1\end{array}$ & $\begin{array}{l}\text { Cholesterol } \\
\text { synthesis, Ketone } \\
\text { body catabolism }\end{array}$ & 1.274 & 1.016 & 1.457 & 3.591 \\
\hline$M$ & P51175 & Ppox & $\begin{array}{l}\text { Protoporphyrinogen } \\
\text { oxidase }\end{array}$ & Heme synthesis & 1.462 & 1.008 & 0.995 & 3.029 \\
\hline$M$ & P32020 & Scp2 & $\begin{array}{l}\text { Sterol carrier protein } \\
2\end{array}$ & $\begin{array}{l}\text { Membrane lipid } \\
\text { transport }\end{array}$ & 1.311 & 1.147 & 1.163 & 2.431 \\
\hline$M$ & Q3TWV4 & Ap2m1 & $\begin{array}{l}\text { Adaptor protein-2 } \\
\text { complex subunit mu }\end{array}$ & $\begin{array}{l}\text { Mitochondrial } \\
\text { protein transport }\end{array}$ & 1.115 & 1.236 & 1.339 & 1.900 \\
\hline
\end{tabular}




\begin{tabular}{|c|c|c|c|c|c|c|c|c|}
\hline M & Q3UF58 & Cat & Catalase & $\begin{array}{l}\text { Protection against } \\
\text { oxidative stress }\end{array}$ & 0.795 & 1.036 & 1.968 & 1.795 \\
\hline & Q6P8R3 & Pf4 & Pf4 protein & Chemokine & 1.361 & 1.033 & 2.174 & 8.062 \\
\hline & A2AFS3 & Kiaa1324 & $\begin{array}{l}\text { UPF0577 protein } \\
\text { KIAA1324 }\end{array}$ & $\begin{array}{l}\text { Stress response } \\
\text { Autophagy }\end{array}$ & 1.080 & 1.140 & 2.282 & 1.997 \\
\hline & Q8BXA1 & Golim4 & $\begin{array}{l}\text { Golgi integral } \\
\text { membrane protein } 4\end{array}$ & $\begin{array}{l}\text { Endosome } \\
\text { trafficking }\end{array}$ & 0.812 & 1.565 & 2.036 & 1.552 \\
\hline & P15261 & Ifngr1 & $\begin{array}{l}\text { Interferon gamma } \\
\text { receptor } 1\end{array}$ & Signalling & 0.867 & 1.260 & 3.475 & 1.515 \\
\hline & Q3UKC1 & Tax1bp1 & $\begin{array}{l}\text { Tax1-binding protein } \\
1 \text { homolog }\end{array}$ & Anti-apoptosis & 0.768 & 1.563 & 2.363 & 1.226 \\
\hline & O88746 & Tom1 & Target of Myb protein & $\begin{array}{l}\text { Intracellular } \\
\text { trafficking }\end{array}$ & 1.307 & 1.130 & 1.878 & 1.160 \\
\hline & P08032 & Spta1 & $\begin{array}{l}\text { Spectrin alpha chain, } \\
\text { erythrocytic } 1\end{array}$ & Cytoskeleton & 0.731 & 0.858 & 1.338 & 3.735 \\
\hline & Q3U5H8 & Hmox1 & Heme oxygenase 1 & Heme catabolism & 0.744 & 0.859 & 1.785 & 2.444 \\
\hline & Q8BJ71 & Nup93 & $\begin{array}{l}\text { Nuclear pore complex } \\
\text { protein } 93\end{array}$ & Nuclear Transport & 0.839 & 0.894 & 1.314 & 2.284 \\
\hline & P11031 & Sub1 & $\begin{array}{l}\text { Activated RNA } \\
\text { polymerase II } \\
\text { transcriptional } \\
\text { coactivator p15 }\end{array}$ & Transcription & 1.398 & 0.928 & 1.105 & 2.226 \\
\hline & Q8VIJ6 & Sfpq & $\begin{array}{l}\text { Splicing factor, } \\
\text { proline- and } \\
\text { glutamine-rich }\end{array}$ & mRNA processing & 0.864 & 1.082 & 1.197 & 2.195 \\
\hline & Q93092 & Taldo1 & Transaldolase & $\begin{array}{l}\text { Pentose } \\
\text { phosphate } \\
\text { pathway }\end{array}$ & 0.999 & 0.981 & 1.277 & 2.086 \\
\hline & Q8VDD5 & Myh9 & Myosin-9 & Cytoskeleton & 1.329 & 0.955 & 1.470 & 2.077 \\
\hline & P15089 & Сpa3 & $\begin{array}{l}\text { Mast cell } \\
\text { carboxypeptidase A }\end{array}$ & Proteolysis & 0.945 & 0.803 & 1.540 & 2.041 \\
\hline & A3KFU5 & Pabpc4 & $\begin{array}{l}\text { Polyadenylate - } \\
\text { binding protein } 4\end{array}$ & mRNA turnover & 1.177 & 1.567 & 1.379 & 2.020 \\
\hline M & Q3TSX8 & Tomm70a & Tomm70a & Protein transport & 0.503 & 0.721 & 0.663 & 0.551 \\
\hline M & Q923F9 & Ndufs4 & $\begin{array}{l}\text { NADH dehydrogenase } \\
\text { (Ubiquinone) Fe-S } \\
\text { protein } 4\end{array}$ & $\begin{array}{l}\text { Electron transport } \\
\text { complex I } \\
\text { assembly }\end{array}$ & 0.457 & 0.827 & 0.854 & 0.518 \\
\hline M & Q3THM1 & Uqcrc1 & $\begin{array}{l}\text { Cytochrome b-c1 } \\
\text { complex subunit } 1\end{array}$ & $\begin{array}{l}\text { Electron transport } \\
\text { complex III subunit }\end{array}$ & 0.437 & 0.802 & 0.925 & 0.509 \\
\hline M & Q3UVI9 & Abcf2 & $\begin{array}{l}\text { ATP-binding cassette } \\
\text { F2 }\end{array}$ & Transport & 0.347 & 0.989 & 1.054 & 1.160 \\
\hline M & Q9DB77 & Uqcrc2 & Cytochrome b-c1 & Electron transport & 0.330 & 0.840 & 0.830 & 0.522 \\
\hline
\end{tabular}




\begin{tabular}{|c|c|c|c|c|c|c|c|c|}
\hline & & & complex subunit 2 & complex III subunit & & & & \\
\hline & A0JLV3 & Hist1h2bj & Histone H2B & $\begin{array}{l}\text { Chromatin } \\
\text { packaging }\end{array}$ & 0.877 & 0.613 & 1.516 & 1.762 \\
\hline & P62806 & Hist1h4a & Histone H4 & $\begin{array}{l}\text { Chromatin } \\
\text { packaging }\end{array}$ & 0.847 & 0.606 & 1.024 & 0.989 \\
\hline & Q8K0C4 & Cyp51a1 & $\begin{array}{l}\text { Lanosterol 14-alpha } \\
\text { demethylase }\end{array}$ & Sterol synthesis & 0.620 & 0.513 & 0.506 & 0.900 \\
\hline & Q3UWV5 & Scin & Adseverin & $\begin{array}{l}\text { Cytoskeleton } \\
\text { remodelling }\end{array}$ & 0.493 & 0.800 & 1.511 & 1.228 \\
\hline & Q8CC06 & $\operatorname{ltga6}$ & Integrin alpha 6 & $\begin{array}{l}\text { Adhesion, } \\
\text { Signalling }\end{array}$ & 0.490 & 0.751 & 0.926 & 0.598 \\
\hline & Q3TED2 & Pdcd6ip & $\begin{array}{l}\text { Programmed cell } \\
\text { death } 6 \text {-interacting } \\
\text { protein }\end{array}$ & $\begin{array}{l}\text { Vesicular protein } \\
\text { sorting }\end{array}$ & 0.487 & 0.805 & 1.310 & 0.742 \\
\hline & Q91VU2 & Tagln2 & Transgelin-2 & Function unknown & 0.471 & 0.697 & 1.082 & 0.876 \\
\hline & Q3UYN7 & Fut8 & $\begin{array}{l}\text { Alpha- }(1,6)- \\
\text { fucosyltransferase }\end{array}$ & $\begin{array}{l}\text { Protein } \\
\text { glycolsylation }\end{array}$ & 0.454 & 1.094 & 1.430 & 0.704 \\
\hline & Q3U7R1 & Esyt1 & $\begin{array}{l}\text { Extended } \\
\text { synaptotagmin-1 }\end{array}$ & $\begin{array}{l}\text { Membrane lipid } \\
\text { transport }\end{array}$ & 0.428 & 0.889 & 0.895 & 0.617 \\
\hline & P70441 & Slc9a3r1 & $\begin{array}{l}\mathrm{Na}(+) / \mathrm{H}(+) \text { exchange } \\
\text { regulatory cofactor } 1\end{array}$ & $\begin{array}{l}\text { Membrane } \\
\text { scaffold }\end{array}$ & 0.421 & 0.862 & 1.654 & 1.020 \\
\hline & A2AJ26 & Abca2 & $\begin{array}{l}\text { ATP-binding cassette } \\
\text { A2 }\end{array}$ & $\begin{array}{l}\text { Cholesterol } \\
\text { transport }\end{array}$ & 0.402 & 1.137 & 1.758 & 0.695 \\
\hline & Q32ME1 & Atp2b4 & $\begin{array}{l}\text { Plasma membrane } \\
\text { calcium transporting } \\
\text { ATPase } 4\end{array}$ & Calcium transport & 0.326 & 0.781 & 0.991 & 0.808 \\
\hline$M$ & Q03265 & Atp5a1 & $\begin{array}{l}\text { ATP synthase subunit } \\
\text { alpha }\end{array}$ & $\begin{array}{l}\text { Oxidative } \\
\text { phosphorylation }\end{array}$ & 0.512 & 0.801 & 0.801 & 0.472 \\
\hline M & Q99LC3 & Ndufa10 & $\begin{array}{l}\text { NADH dehydrogenase } \\
\text { [ubiquinone] } 1 \text { alpha } \\
\text { subcomplex subunit } \\
10\end{array}$ & $\begin{array}{l}\text { Electron transport } \\
\text { complex I subunit }\end{array}$ & 0.455 & 0.799 & 0.751 & 0.451 \\
\hline$M$ & A2AC46 & Abcb7 & $\begin{array}{l}\text { ATP-binding cassette } \\
\text { B7 }\end{array}$ & Transport & 0.435 & 0.722 & 0.698 & 0.392 \\
\hline$M$ & Q6PF96 & Etfdh & $\begin{array}{l}\text { Electron transfer } \\
\text { flavoprotein- } \\
\text { ubiquinone } \\
\text { oxidoreductase }\end{array}$ & Electron transport & 0.394 & 0.827 & 1.006 & 0.408 \\
\hline M & A8ASF5 & Cpt1a & $\begin{array}{l}\text { Carnitine } \\
\text { palmitoyltransferase } \\
\text { 1a }\end{array}$ & $\begin{array}{l}\text { Fatty acid } \\
\text { oxidation }\end{array}$ & 0.284 & 0.585 & 0.605 & 0.302 \\
\hline & Q922J9 & Far1 & $\begin{array}{l}\text { Fatty acyl-CoA } \\
\text { reductase } 1\end{array}$ & $\begin{array}{l}\text { Fatty acid } \\
\text { metabolism }\end{array}$ & 0.391 & 0.517 & 0.435 & 0.302 \\
\hline & E9Q1G8 & Sept7 & Septin-7 & Cytoskeleton & 0.284 & 0.551 & 0.522 & 0.296 \\
\hline
\end{tabular}




\begin{tabular}{|c|c|c|c|c|c|c|c|c|}
\hline & Q60766 & Irgm1 & $\begin{array}{l}\text { Immunity-related } \\
\text { GTPase family M } \\
\text { protein } 1\end{array}$ & $\begin{array}{l}\text { Innate immune } \\
\text { response }\end{array}$ & 0.403 & 0.774 & 1.101 & 0.475 \\
\hline & P18181 & Cd48 & CD48 antigen & $\begin{array}{l}\text { Cell-cell } \\
\text { interaction }\end{array}$ & 0.310 & 0.647 & 0.769 & 0.451 \\
\hline & D3Z3V3 & Sept1 & Septin-1 & Cytoskeleton & 0.280 & 0.573 & 0.627 & 0.362 \\
\hline M & Q60930 & Vdac2 & $\begin{array}{l}\text { Voltage-dependent } \\
\text { anion-selective } \\
\text { channel protein } 2\end{array}$ & $\begin{array}{l}\text { Membrane } \\
\text { channel }\end{array}$ & 0.778 & 1.034 & 0.770 & 0.513 \\
\hline M & Q99JR1 & Sfxn1 & Sideroflexin-1 & Transport & 0.631 & 0.744 & 0.749 & 0.510 \\
\hline M & Q9CR68 & Uqcrfs1 & $\begin{array}{l}\text { Cytochrome b-c1 } \\
\text { complex subunit } \\
\text { Rieske }\end{array}$ & $\begin{array}{l}\text { Electron transport } \\
\text { complex III subunit }\end{array}$ & 0.551 & 0.967 & 0.971 & 0.489 \\
\hline M & P53702 & Hccs & $\begin{array}{l}\text { Cytochrome c-type } \\
\text { heme lyase }\end{array}$ & $\begin{array}{l}\text { Cytochrome C } \\
\text { synthesis }\end{array}$ & 0.617 & 0.830 & 0.838 & 0.465 \\
\hline M & Q9DCX2 & Atp5h & $\begin{array}{l}\text { ATP synthase subunit } \\
\text { d }\end{array}$ & $\begin{array}{l}\text { Oxidative } \\
\text { phosphorylation }\end{array}$ & 0.499 & 0.754 & 0.869 & 0.444 \\
\hline M & Q3TWH2 & Nnt & $\begin{array}{l}\text { Nicotinamide } \\
\text { nucleotide } \\
\text { transhydrogenase }\end{array}$ & $\begin{array}{l}\mathrm{NAD}(\mathrm{H}) / \mathrm{NADP}(\mathrm{H}) \\
\text { balance }\end{array}$ & 0.606 & 0.872 & 0.681 & 0.430 \\
\hline M & Q64521 & Gpd2 & $\begin{array}{l}\text { Glycerol-3-phosphate } \\
\text { dehydrogenase } 2\end{array}$ & Electron transport & 0.594 & 0.807 & 0.867 & 0.415 \\
\hline M & Q9D880 & Timm50 & $\begin{array}{l}\text { Mitochondrial import } \\
\text { inner membrane } \\
\text { translocase TIM50 }\end{array}$ & Protein transport & 0.526 & 0.773 & 0.800 & 0.394 \\
\hline M & Q8BGT5 & Gpt2 & $\begin{array}{l}\text { Alanine } \\
\text { aminotransferase } 2\end{array}$ & $\begin{array}{l}\text { Amino acid } \\
\text { metabolism }\end{array}$ & 1.067 & 1.027 & 0.785 & 0.359 \\
\hline & E9QPE8 & Plec & Plectin & Cytoskeleton & 0.553 & 0.900 & 0.939 & 0.500 \\
\hline & Q921E2 & Rab31 & $\begin{array}{l}\text { Ras-related protein } \\
\text { Rab-31 }\end{array}$ & $\begin{array}{l}\text { ER Golgi Protein } \\
\text { transport }\end{array}$ & 0.651 & 0.789 & 0.865 & 0.456 \\
\hline & A2AVJ7 & Rrbp1 & $\begin{array}{l}\text { Ribosome-binding } \\
\text { protein } 1\end{array}$ & Translation & 0.472 & 0.791 & 1.088 & 0.429 \\
\hline & Q9ERI2 & Rab27a & $\begin{array}{l}\text { Ras-related protein } \\
\text { Rab-27A }\end{array}$ & Exocytosis & 1.013 & 0.875 & 0.688 & 0.408 \\
\hline
\end{tabular}

